\title{
An occurrence of Ammobaculites (Foraminiferida, Lituolacea) in the Purbeck Formation (late Jurassic-early Cretaceous) of Dorset, south-west England
}

\author{
JON D. RADLEY \\ Museum of Isle of Wight Geology, \\ High Street, Sandown \\ Isle of Wight PO36 8AF, UK.
}

\begin{abstract}
An influx of Ammobaculites cf. obliquus Loeblich \& Tappan is documented from the late Jurassic-early Cretaceous Purbeck Formation of Dorset, south-west England. The foraminifera are interpreted as inhabitants of a dysaerobic, muddy, brackish lagoonal environment. J. Micropalaeontol., 12 (1): 119-120 August 1993.
\end{abstract}

\section{INTRODUCTION}

Foraminifera have only occasionally been noted from the predominantly non-marine Purbeck Formation of Dorset, southern England (late Portlandian to Berriasian, see Allen \& Wimbledon, 1991) and have never been documented in any detail. The few records indicate sporadic occurrences of both agglutinated and calcareous taxa (e.g. Clements, 1973; Robertson Research, 1974; West, 1975). By contrast, ostracods and molluscs are abundant and relatively well-researched (e.g. Anderson, 1985; Clements, 1969, 1973).

This note documents a monospecific population of Ammobaculites cf. obliquus Loeblich \& Tappan in the Corbula Beds of Durlston Bay, Swanage, Dorset, for the first time. These strata occur in the upper part of the Middle Purbeck Beds (Clements, 1969) and are probably late Berriasian in age (Allen \& Wimbledon, 1991).

\section{OCCURRENCE AND PRESERVATION}

Clements (1973) first recorded agglutinated foraminifera in bed DB168 (Corbula Beds) of his account at Durlston Bay, near Swanage (SZ 0377, SZ 0378) but did not attempt to name them. DB168 is the equivalent of Bed 150 of a new section being prepared by Wimbledon et al. (Fig. 1). The author has recently re-sampled the bed (pyritic and selenitic dark shale with intercalated calcarenite, approximately $0.6 \mathrm{~m}$ thick), in the northern part of Durlston Bay (SZ 0384 7851). These samples have yielded abundant finely siliceous, but crushed, Ammobaculites, with rarer molluscan and ostracod debris.

\section{IDENTIFICATION}

Ammobaculites from DB 168/Bed 150 (Fig. 2a,b) agree well with Ammobaculites obliquus Loeblich \& Tappan, described and figured from the Upper Valanginian and Hauterivian of the Lusitanian Basin, west Portugal (Wightman, 1990), from the Lower Aptian of the southeast Paris Basin (Damotte \& Magniez-Jannin, 1973) and the Lower Aptian of the Isle of Wight, southern England (Crittenden, 1983). The Purbeck tests are smaller than those originally described from the Albian Kiowa Shale of Kansas by Loeblich \& Tappan (1949, 1950), but are otherwise comparable in morphology. They are consequently identified as $A$. cf. obliquus. Similar, larger, A. obliquus also occur in the Vectis Formation (Wealden Group, Barremian or possibly up to Lower Aptian) of the Isle of Wight, southern England (Radley, in prep.).

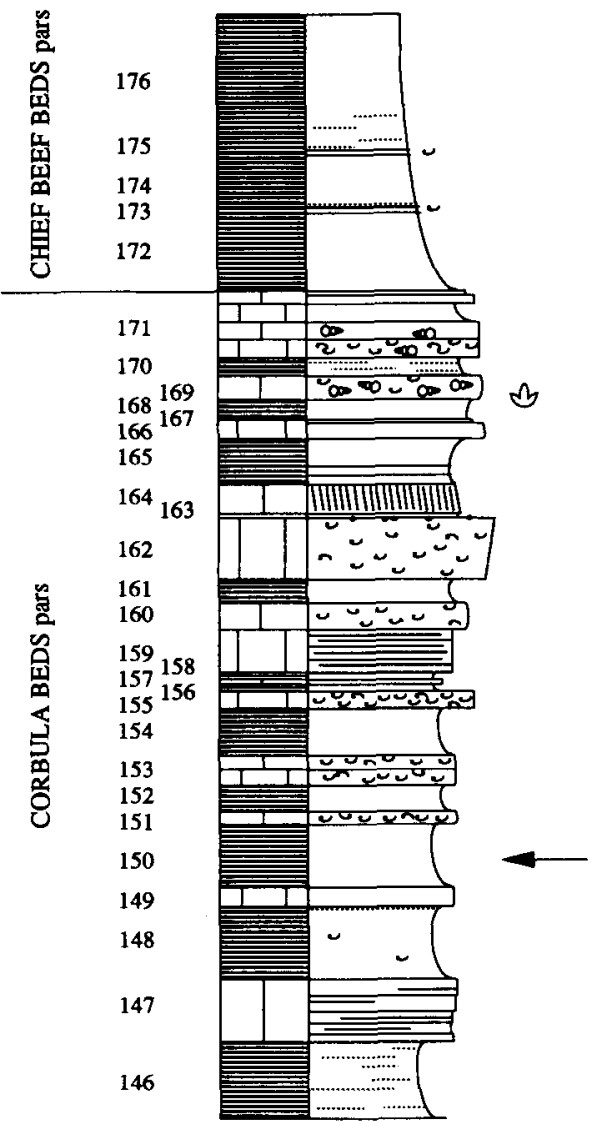

Fig. 1 Stratigraphic relations of foraminiferal horizon in the Durlston Bay section (from Wimbledon et al. in prep).

\section{PALAEOECOLOGY}

The shelly carbonates and mudstones which constitute much of the Purbeck Formation were deposited in and around an extensive shallow lagoon of fluctuating salinity. Semi-arid climates prevailed during early Purbeck times but later gave way to more humid, warm-temperate conditions (El-Shahat \& West, 1983). The ostracod and molluscan faunas indicate fluctuating salinities, ranging form hypersaline through brackish to freshwater (e.g. Clements, 1969; Anderson, 1985).

The Corbula Beds have been interpreted as moderate brackish ("mesohaline") lagoonal deposits (Clements, 1969; 


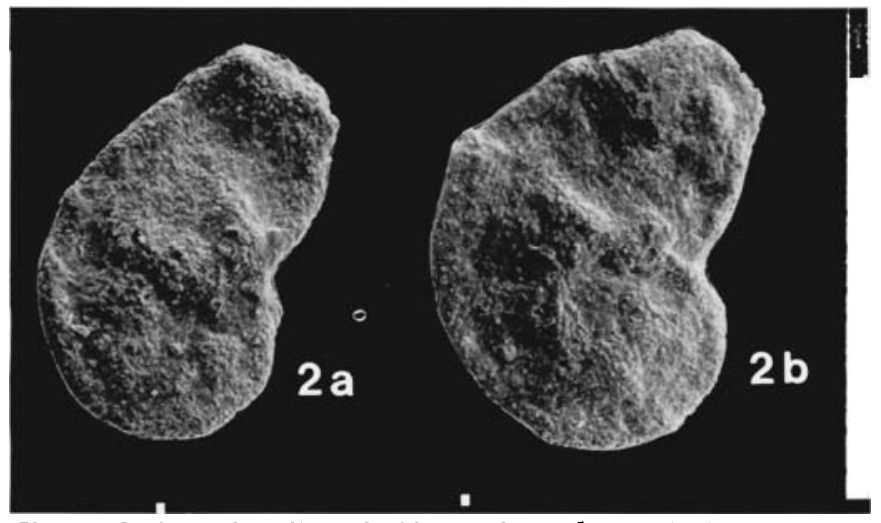

Fig. 2 a,b Ammobaculites cf. obliquus from the Corbula Beds, Purbeck Formation, Durlston Bay, Swanage, Dorset. 2a x 104, $2 \mathrm{~b} \times 125$.

El-Shahat \& West, 1983). The limestones formed largely as molluscan shell accumulations on marginal flats (El-Shahat \& West, 1983); intercalated fossiliferous shales are accordingly of shallow subaqueous or mud flat origin.

The foraminiferal tests generally lack signs of abrasion, indicating little or no post mortem transport. The presence of scattered calcareous molluscan and ostracod debris in the samples indicates that the shale has not been decalcified. The foraminifera thus represent a true monospecific agglutinated assemblage.

Dense monospecific Ammobaculites populations occur in Recent brackish lagoons and estuaries of moderate temperature, where they characterise argillaceous substrates. These brackish-water species appear to be highly opportunistic and sometimes inhabit poorly-oxygenated muds. Many prefer salinities in the range of 12.5-15 parts per thousand, although they tolerate salinity fluctuations (Ellison, 1972). Extant Ammobaculites appear to feed on bacteria and other organic detritus and live both infaunally and epifaunally (Jones \& Charnock, 1985; Nagy, 1992).

Purbeck $A$. cf. obliquus are similarly interpreted here as environmentally-tolerant opportunists, which inhabited muddy, brackish, lagoonal substrates or marginal mud-flats. Ostracods and molluscs are rare in the sampled shale (see above), but occur commonly in the overlying and subjacent strata, which lack foraminifera (Clements, 1969, 1973). It therefore seems likely that the foraminiferal shale was deposited under ephemeral dysaerobic conditions, excluding most benthos, but allowing $A$. cf. obliquus to temporarily thrive.

Recently, monospecific Ammobaculites accumulations have been documented from Berriasian to Hauterivian strata of the Lusitanian Basin, western Portugal by Wightman (1990). Here, similar finely-agglutinated $A$. obliquus was intepreted as a grain-selective, upper estuarine mud-flat inhabitant.

\section{ACKNOWLEDGMENTS}

I would like to thank Roy Clements, Bill Wimbledon and John Nunn for supplying unpublished data concerning the Durlston Bay section. Dave Shipp of Simon Petroleum Technology (formerly Robertson Research) is thanked for releasing data from the Roberston Research report and Ian West is acknowledged for discussion of the Purbeck strata. Gratitude is also expressed to Steve Crittenden and Bill Wimbledon for commenting on the manuscript. Assistance with photography was provided by geological technical staff of the University of Southampton and Robin Whatley and Steve Tatman of the Micropalaeontology Research Group, University College of Wales, Aberystwyth.

\section{REFERENCES}

Allen, P., \& Wimbledon, W.A. 1991. Correlation of NW European Purbeck-Wealden (nonmarine Lower Cretaceous) as seen from the English type-areas. Cret. Research, 12, 511-526.

Anderson, F.W. 1985. Ostracod faunas in the Purbeck and Wealden of England. J. Micropalaeontol., 4, 1-67.

Clements, R.G. 1969. The Purbeck Beds. In: Torrens, H.S.; ed.) International Field Symposium on the British Jurassic. A57-A64. Keele University.

Clements, R.G. 1973. A study of certain non-marine Gastropoda from the Purbeck Beds of England. Unpublished PhD thesis, University of Hull.

Crittenden, S. 1983. A foraminiferal analysis of the Atherfield Clay (Lower Aptian) of the Isle of Wight, U.K., with special emphasis on the arenaceous species. In: Verdenius, J.G., van Hinte, J.E. \& A.R. Fortuin (eds), Proceedings of the First Workshop on Arenaceous Foraminifera 7th-9th September 1981, 9-29. IKU, Norway.

Damotte, R. \& Magniez-Jannin, F. 1973. Ostracodes et foraminifères de l'Aptien inférieur du sondage du Bois du Perchois (Aube). Bull. Inf. Géol. Bass. Paris, 36, 3-47.

Ellison, R.L. 1972. Ammobaculites, foraminiferal proprietor of Chesapeake Bay estuaries. Mem. Geol. Soc. Am., 133, 247-262.

El-Shahat, A. \& West, I.M. 1983. Early and late lithification of aragonitic bivalve beds in the Purbeck Formation (Upper JurassicLower Cretaceous) of southern England. Sed. Geol. 35, 15-41.

Jones, R.,W. \& Charnock, M.A. 1985. "Morphogroups" of agglutinating foraminifera. Their life positions and feeding habits and potential applicability in (paleo)ecological studies. Rev. Paléobiol., 4, 311-320.

Loeblich, A.R. \& Tappan, H. 1949. New Kansas Lower Cretaceous Foraminifera. J. Wash. Acad. Sci., 39, 90-92.

Loeblich, A.R. \& Tappan H. 1950. Foraminifera from the type Kiowa Shale, Lower Cretaceous, of Kansas. Univ. Kansas Paleont. Contrib., 3, 1-15.

Nagy, J. 1992. Environmental significance of foraminiferal morphogroups in Jurassic North Sea deltas. Palaeogeogr., Palaeoclimatol., Palaeoecol., 95, 111-134.

Radley, J.D. in prep. A foraminiferal datum in the Wealden Group (Lower Cretaceous) of the Isle of Wight, southern England.

Robertson Research International Limited, 1974. The Jurassic of Northwest Europe: onshore project. Petroleum Industry Report.

West, I.M. 1975. Evaporites and associated sediments of the basal Purbeck Formation (Upper Jurassic) of Dorset. Proc. Geol. Ass., 86, 205-225.

Wightman, W.G. 1990. Estuarine and marsh foraminifera from the Lower Cretaceous of the Lusitanian Basin, Western Portugal., pp. 739-764. In: Hemleben, C., Kaminski, M.A., Kuhnt, W. \& D.B. Scott (eds) Paleoecology, Biostratigraphy, Paleoceanography and Taxonomy of Agglutinated Foraminifera. NATO ASI Series C: Mathematical and Physical Sciences, 327, 739-764. Kluwer, Dordrecht.

Wimbledon, W.A., Allen, P., Parker, A., Ogg, J., Hunt, C.O. \& Nunn, J. in prep. Portland-Purbeck type sections: their stratigraphy, palynology, clay mineralogy and palaeomagnetism. 